\title{
Ants, Spiders or Bees . . . and Ticks? A Typology of Old Testament Scholarship in South Africa since 1994 within Its African Context
}

\author{
HENDRIK L. BOSMAN (STELLENBOSCH UNIVERSITY)
}

\begin{abstract}
Looking back over the past two decades of oT scholarship in South Africa, trends emerge that to some extent resemble the taxonomy of scientific endeavour made by Francis Bacon ${ }^{1}$ in 1620: (i) Like ants, some of us prefer to collect philological data to engage with biblical texts primarily on a literary and synchronic level. (ii) Others are like spiders who on a diachronic level produce ("spin"?) new hypotheses about the (re)construction of elements of ancient Israel's past as history. (iii) There are also the odd few bees who try to relate and even integrate synchronic and diachronic interpretations of biblical texts that will result in producing "theological-ethical honey" as nourishment for faith communities (especially in different African contexts). Bees can be found in widely diverging scholarly contexts: i.e. "theological-ethical honey" can manifest itself in different modes such as African, Black and Feminist theologies. A fourth metaphor, "tick," is added to the threefold taxonomy formulated by Francis Bacon in order to stimulate some reflection on the agency of oT scholarship in South Africa. In conclusion, the distinction made by Antonio Gramsci between "traditional" and "organic" intellectuals is combined with Paulo Freire's concept of "critical pedagogy" to suggest a way forward beyond the past two decades of oT scholarship.
\end{abstract}

KEYWORDS: OT scholarship, Africa, typology, hermeneutics, ecology.

\section{A INTRODUCTION}

This contribution is obviously not an attempt, paraphrasing the immortal words of Dale Carnegie, "to win friends and influence people." Rather, it is to identify scholarly trends and to stimulate more critical self-awareness amongst fellow OT travellers on the dusty but exciting roads of our beloved African continent! It is also not an exercise to pigeonhole colleagues according to a five hundred

* Article submitted: 21 September 2015; accepted: 3 November 2015. To cite: Hendrik L. Bosman, "Ants, Spiders or Bees ... and Ticks? A Typology of Old Testament Scholarship in South Africa since 1994 within Its African Context," Old Testament Essays 28, no. 3 (2015): 636-654. DOI: http://dx.doi.org/10.17159/2312- 3621/2015/ v28n5a5

1 Francis Bacon, Novum Organum (ed. and trans. Peter Urbach and John Gibson; Chicago: Open Court, 1994 [1620]). 
year old taxonomy but a cautious survey about possible trends that can be discerned in our local OT scholarship within the context of the study of the OT on the continent of Africa, without going into much individual detail.

The title of this article requires some explanation: I have added a fourth entomological metaphor, "tick," to the threefold taxonomy described by Francis Bacon which will be explained in the conclusion. Furthermore, the phrase "within its African context" was added to make our topic less parochial and also of some interest to several colleagues from different parts of the African continent and further abroad.

The article will comprise of the following elements:

- A short explanation of the taxonomy of science by Francis Bacon;

- A brief typology of OT scholarship in South Africa within the African continent since 1994;

- Suggestions about the way forward by means of Antonio Gramsci and Paulo Freire;

- Conclusion.

\section{B TAXONOMY OF SCIENCE BY FRANCIS BACON [1561-1626]}

Francis Bacon "wrote that good scientists are not like ants (mindlessly gathering data) or spiders (spinning empty theories). Instead, they are like bees, transforming nature into a nourishing product."2 In his Novum Organum (1620), Bacon summarised his taxonomy of the science of his day thus:

Those who have handled the sciences have been either Empiricists or Rationalists. Empiricists, like ants, merely collect things and use them. The Rationalists, like spiders, spin webs out of themselves. The middle way is that of a bee, which gathers its material from the flowers of the garden and field, but then transforms and digests it by a power of its own. ${ }^{3}$

Bacon's aphoristic and metaphorical style of establishing an "entomological" taxonomy of science makes implicit claims about the nature of science in general that can be explicated in individual scientific disciplines (like OT studies) in particular. ${ }^{4}$

2 Cited in Madeline M. Muntersbjorn, "Francis Bacon's Philosophy of Science: Machina Intellectus and Forma Indita," PhSc 70 (2003): 1137.

3 Bacon, Novum Organum, 95.

4 It is interesting that almost a century earlier, Martin Luther in a sermon conducted on Trinity Sunday, 23 May 1535 stated that the Rule of Faith (regula fidei) "functioned as an interpretive assumption more than an overt hermeneutical tool: 'This con- 


\section{BRIEF TYPOLOGY OF OLD TESTAMENT SCHOLARSHIP IN SOUTH AFRICA SINCE 1994}

From the outset, it must be stated that pride of place is given to "bees" (those scholars who try to relate and even integrate synchronic and diachronic interpretations of biblical texts that will result in producing "theological-ethical honey" as nourishment for faith communities). But OT studies (in South Africa) cannot make do without the on-going input from "ants" (biblical scholars who prefer to collect philological data to engage with biblical texts primarily on a literary and synchronic level), as well as from "spiders" (OT scholars who on a diachronic level produce ["spin"] new hypotheses about the [re]construction of elements of ancient Israel's past as history).

\section{Background of Early South African Scholarship (1957-1987)}

In his monograph, A Story of Two Ways, Jurie Le Roux wrote a history of OT scholarship in South Africa that covered the period from 1957 to 1987. From the formation of the "Old Testament Society of South Africa" in December 1957, thirty years of scholarship was described as "the flowering of Old Testament scholarship in South Africa" due to favourable economic developments and a significant interest in Biblical Studies at matriculation level. ${ }^{5}$ Thousands of teachers required training and many job opportunities were created for young biblical scholars. Who can forget the Old and New Testament Department at UNISA which in the middle of the 1980s had more than 40 lecturers on its payroll! Many biblical scholars during these thirty years adhered to a preEnlightenment hermeneutics that at most tolerated "historical-grammatical exegesis" - historical-critical exegesis was just an epistemological bridge too far!

Over and above this less critical diachronic engagement with the biblical texts, a more synchronic focus on the Hebrew (MT) text of the OT emerged from the 1970s onwards. It was as if the traumatic memories of the so-called Du Plessis heresy trial of the early 1930s still lingered and this made most biblical scholars very reluctant to dabble into critical diachronic exegesis. It seemed safer to engage in synchronic interpretations of the biblical text in which the "final form" of the Hebrew text and a systematic exegetical method-

fession of faith we did not make or invent, neither did the fathers of the church before us. But as the bee gathers honey from many a beautiful and delicious flower, so this creed has been collected in commendable brevity from the books of the beloved prophets and apostles, that is, from the entire Holy Scriptures, for children and plain Christians." Cited in Samuel D. Giere, “'As a Bee Gathers Honey': The Rule of Faith in Luther's Interpretation of the Old Testament," CurTM 41 (2014): 39-40; Muntersbjorn, "Francis Bacon's Philosophy," 1142).

5 Jurie H. le Roux, A Story of Two Ways: Thirty Years of Old Testament Scholarship in South Africa (Pretoria: Verba Vitae, 1993), 351. 
ology became paramount. This rigorous "immanent" engagement with the biblical text established a reading model that was less concerned with the context of text production then and the context of text reception now. A new breed of biblical scholar therefore emerged in South Africa that Le Roux quaintly referred to as "text mechanics." Even more importantly, the "immanent reading" of the biblical text resulted in a theological perspective according to which "God became more and more an abstraction from the text and was separated from life." 6

In 1994, Ferdinand Deist discussed the topic "South African Old Testament Studies and the Future" in Old Testament Essays 7/4. ${ }^{7}$ Deist warned the members of the local OT guild of "one area in which we have not made much progress, namely in the field of Old Testament theology." Deist concluded that it was shocking that the OTSSA had only three black members out of 158 in $1994 .^{8}$

\section{$2 \quad$ Africa (as Continent) as Context}

The trends in OT scholarship in South Africa must also be related to biblical scholarship on the larger African continent. In a survey of HB/OT Scholarship on the African continent (edited by Magne Saebo and recently published in January 2015), I made the following observations about recent trends:

The following threefold division between pre-modern, modern and post-modern approaches to the interpretation of the Old Testament in Africa must not be seen as three consecutive stages in chronological order, since they can co-exist within the same period of time and within the same cultural or geographical setting.

(i) Pre-modern approaches are closely linked with the pre-critical interpretation of the Old Testament that constituted an almost seamless continuation of the initial missionary biblical interpretation that was characterized by a theologically conservative and evangelical approach. At the same time a pre-critical (which is not synonymous with uncritical) continuity develops between traditional African religions and the seemingly familiar Old Testament.

(ii) Modern approaches resonate with the more critical interpretation of the Old Testament that resulted in the quest for an African Theology undergirded by critical biblical exegetical strategies. Reading

6 Le Roux, A Story of Two Ways, 352, 353.

7 In Old Testament Essays 7/4, no less than 39 articles were published on the African or South African orientation of OT Studies. Numerous models of literary, historical and theological interpretations of the biblical text were discussed to supplement Le Roux's The Story of Two Ways. Ferdinand E. Deist, "South African Old Testament Studies and the Future," OTE 7/4 (1994): 34-51.

8 Deist, "South African," 36. 
strategies for the Old Testament now became based on critical interpretive models like historical criticism. Readers of the Old Testament who were trained in the Northern Hemisphere were expected to be objective, decontextualized and impartial readers of texts, toeing the methodological line determined by the guild of Old Testament scholars.

(iii) Post-modern approaches are slowly emerging where the cultural diversity of the African continent is taken seriously and therefore attempting to articulate authentic African interpretations of the Old Testament that make sense in local contexts and that do not assume to be equally valid in all cultural contexts on the African continent. Therefore the reception of flesh-and-blood African readers of the Old Testament entail taking serious cognizance of their local social locations without aspiring to be relevant for the African continent as a whole (Segovia 1998: 49-51). These local readings of the Old Testament are usually liberative in nature striving towards constructive theological discourse that allows diversity and pluralism, emphasizing human dignity for those in the centre and in the margins of society, allowing critical dialogue for those in asymmetrical power relations. 9

\section{Interpreting from African (Cultural/Plural) Perspectives}

The focus now shifts from a more general perspective on Africa to a more specific evaluation of OT scholarship in South Africa. When describing modern approaches to the study of the OT in Africa, one is confronted with the thorny and sensitive issue of how South African OT scholarship (often characterised as a white male dominated academic enterprise) relates to the rest of Africa. Up to the 1980s, influential scholars like John Mbiti were of the opinion that white South African biblical scholarship was "still European" and "closed to the realities of African presence"; therefore, he did not include "this strand of Christianity" in his discussion of the Bible in African Christianity. ${ }^{10}$ Even twenty years later South African scholars such as Maluleke and Nadar still argue that that studies by white male scholars of black scholarship amount to "fake" academic discourse that serves as a "pretext for the exoneration of White and male guilt." 11

9 Hendrik L. Bosman, "The Hebrew Bible/Old Testament Studies in Africa," in From Modernism to Post-Modernism (The Nineteenth and Twentieth Century) (vol. 3 of The Hebrew Bible/Old Testament: The History of Its Interpretation; ed. Magne Saebo; Göttingen: Vandenhoeck \& Ruprecht, 2015), 262-263.

10 John S. Mbiti, Bible and Theology in African Christianity (Nairobi: Oxford University Press, 1986), 17-18.

11 The topic of "agency" within South African OT scholarship will subsequently receive more attention in this typology. Tinyiko S. Maluleke and Sarojini Nadar, 
More than twenty years ago, Itumeleng Mosala ${ }^{12}$ was seen as a good example of a self-critical approach to biblical studies as an academic discipline and to the Bible itself from the perspective of Black Theology. He critiqued the exegetical point of departure found in most Black Theology - the Bible as the revealed Word of God. According to him, the Bible provides glimpses of the liberation of the oppressed even though it was written by the oppressor. Therefore, Black Theology must be informed by both the Bible and African history and culture to the extent that it provides an indication of class struggle and resistance against oppression.

Gerald West also made a creative and critical contribution by rooting his biblical interpretation in the predominantly black struggle for political and socio-economical liberation. Did we make significant progress during the past twenty years in this regard? Some fifteen years later, West reflected on his "vocation as an African Biblical scholar" on what he considers "the margins of Biblical Scholarship." He positions himself by locating his work "both in theory and in practice...within a black (and later) African frame."13 One should then ask: Who can claim to be African and is it possible for white South Africans to be accepted as "Africans," even after embracing African Theology and the struggle context as "primary frame" for one's vocation as an OT scholar working in South Africa? ${ }^{14}$ This "struggle context" goes far beyond race and also entails "class, gender, culture, sexual orientation, disability, globalization and HIV/AIDS" according to West whose "primary interlocutors remain the poor, the working class, and the marginalised" while his "second ring of responsibility is that of African (including South African) biblical scholarship."15 Biblical scholarship in South Africa, according to West entails the

"Alien Fraudsters in the White Academy: Agency in Gendered Colour," JTSA 120 (2004): 5-17.

12 Itumeleng J. Mosala, Biblical Hermeneutics and Black Theology in South Africa (Grand Rapids: Eerdmans, 1989).

13 Gerald O. West, Biblical Hermeneutics of Liberation: Modes of Reading the Bible in the South African Context (Pietermaritzburg: Cluster Publications, 1991). Gerald O. West, "The Vocation of a Biblical Scholar on the Margins of Biblical Scholarship," in Voyages in Unchartered Waters: Essays on the Theory and Practice of Biblical Interpretation in Honour of David Jobling (ed. Wesley J. Bergen and Armin Siedlecki; Sheffield: Sheffield Phoenix Press, 2006), 142-171.

14 West discerned three possible modes of being "an African": a) You are an African if you claim to be one (Tinyiko Maluleke); b) Besides the self-claim to be an African, your black neighbours must agree (Sipho Mtetwa); c) There is also the discourse about white Africans amongst black Africans that white South Africans are not supposed to hear - a discourse that makes the position of white Africans very ambiguous. See West, "Vocation," 145.

15 West, "Vocation," 145-146. West described "white Afrikaner biblical scholarship" as being "characterised by its conservative (or state) theological and political alignment, its close academic ties with Europe (particularly Germany and Holland) and its 
identification of "the poor and oppressed as the primary interlocutors," as well as "a radical reorientation on the part of the biblical scholars ..." which results in both "reading with" the poor as well as "reading for" individual and social transformation. For West, this translates into the "threefold cord" of his pedagogy: "engagement with the Bible, critical distance, contextualisation."16

Recently, West located "Contextual Bible Study" at the interface between "biblical liberation hermeneutics" and "intercultural biblical hermeneutics." He explains that, "Contextual Bible Study is a form of liberation hermeneutics that emerged in South Africa in the 1980s. In it, socially engaged biblical scholars and ordinary readers of the Bible collaborate in the interpretive process, each bringing different sets of critical resources to the interpretive process." He further describes the interpretive process underlying "Contextual Bible Study" as being:

...the See-Judge-Act method, moving from social analysis to biblical reflection to social action. The social analysis and the social action are primarily in the hands of the community of ordinary readers using Contextual Bible Study. The biblical reflection draws on an array of biblical studies resources, and so the shape of the biblical reflection is primarily the contribution of the socially engaged biblical scholar. ${ }^{17}$

In the final analysis the "distinguishing feature of Contextual Bible Study, however, is not in its components but in the collaborative work that configures these components."

Ndikho Mtshiselwa wrote an article "to further the debate on whiteness that result into a paradigm shift from an interpretation influenced by whiteness to an indigenous (Xhosa) biblical interpretation, blackness." He agreed with Jeremy Punt that "a dialogue between both the colonial and the post-colonial readings of the biblical text is possible. This dialogue in essence is paramount

predilection for structuralist exegesis... White English biblical scholarship was characterised by its liberal, contextual and Black and African theological context and its progressive... political orientation, its academic ties with Britain, the United States, Europe and Latin America... its preference for historical-critical and sociological biblical interpretation... Black biblical scholarship was characterised by its overt Black (and later African) Theology context and its clearly committed liberationist political agenda, its eclectic use of European (including British); and American scholarship, and its advocacy of historical-critical and sociological modes of biblical scholarship."

16 West, "Vocation," 152-155, 164.

17 Gerald O. West, "Locating 'Contextual Bible Study' within Liberation Hermeneutics and Intercultural Biblical Hermeneutics," HTS 70/1 (2014), 2; Art. \#2641; DOI: org/10.4102/hts.v70i1.2641. 
in establishing an interaction between whiteness and blackness in South African biblical scholarship."18

Gerrie Snyman made a contribution that can be construed as a step into the direction of the dialogue advocated by Mtshiselwa. According to Snyman, "whiteness has lost its political dominance, but not its cultural and economic domination . . .. Whiteness is in a precarious position and for this reason" Snyman "developed the notion of a hermeneutics of vulnerability . . . a reader awareness of what the effect of reading or interpretation will be on others and for which the reader needs to take responsibility." temic Vulnerability," Snyman describes "vulnerability" as follows:

Vulnerability is a human condition. Negatively it refers to the possibility of being harmed or wounded, either physically or emotionally. When one is open to injury, violation and denigration, there is a need for social justice where the perpetrating agent needs to reciprocate in order to restore the balance. In this restoration process the latter agent, in turn, is rendered vulnerable. Vulnerability is what connects human beings to each other, the basis for reciprocity, survival, prosperity, or simply just being. It is an enabling condition that makes it possible to love and to suffer.

He concludes this editorial with the following challenge that Old Testament scholarship in South Africa has to take note of:

One aspect that needs attention in our scholarship is our epistemic vulnerability: the way we think is shaped by the ideologies and epistemology with which we grew up. Exploitation of other human beings (and nature) can be linked to particular epistemologies that create an arrogant independent invulnerable subject with an illusion of control. ${ }^{20}$

In 2012, Madipoane (ngwa'na Mphahele) Masenya and Hulisani Ramantswana conducted a review of Old Testament Essays from 1994 to 2010. Masenya and Ramantswana quoted Le Roux who noted that, "South African Old Testament scholarship has for the most part been focused on the ancient texts rather than on contemporary issues." As "African Qoheleths," they wonder if "there is anything new under the sun" in South African OT scholarship. These two "African Qoheleths" propose a methodology that is "cast in the form of a story, following the African story-telling approach. The 'story-telling approach... is reader-centered', in so far as the African Qoheleths seek to tell a

18 Ndikho Mtshiselwa, "Towards an Indigenous (Xhosa) South African Biblical Scholarship," OTE 24/3 (2011): 668, 675.

19 Gerrie F. Snyman, "Looking into Black Eyes and Feel the Embarrassment': A Selected and Selective Reading of the Africana Bible," OTE 24/2 (2011): 466.

20 Gerrie F. Snyman, "Editorial: Epistemic Vulnerability," OTE 28/1 (2015): 9, 10. 
story of Old Testament scholarship in South Africa since 1994."21 From the perspective of the African Qoheleths, the call by Deist to go beyond Eurocentric methodologies and hermeneutics "has not been heeded." There is a significant sting in the tail of this survey:

As they ruminate on all of this, the African Qoheleths suddenly remember that many South African OT scholars chose not to prophesy during the period of apartheid in South Africa, a path on which we continue today, 18 years after independence. Perhaps, speculate the Qoheleths of our text, readership of our published works is as elite as ourselves. Perhaps, indeed, there is nothing new under the sun $!^{22}$

\section{Interpreting from Eco-Theological Perspectives}

In 2009, Willie van Heerden took stock of OT scholarship on environmental matters in South Africa. He identified some 33 studies and discussed them in terms of a "hermeneutics of suspicion and retrieval." A threefold typology of these eco-theological studies are provided (covenantal, prophetic and mystic) to highlight the affinities and differences between the 33 studies. In answer to his own question: "Can Old Testament scholarship in South Africa be described as being 'green'?" His wry answer is: "Perhaps, but only in another sense of the word 'green' - fresh on the scene and beginning to find its way.,"23

Peet van Dyk wrote on "Eco-theology and Losing the Sacred" and reminded us that Christianity has often been blamed for our current ecological crisis - i.e. the reception history of Gen 1:18 and Ps 8 etc. - due to the fact that it has lost its sense of the sacred. He argues that the "de-sacralisation or disenchantment of nature" may be linked to a specific cosmology or worldview. Wistfully, he concludes that it is not possible to regain a sense of the sacred unless one is willing to revert back to a "magico-mythical" worldview. Ecotheologians should rather search for metaphors that are more appropriate when arguing for the conservation of the environment. Finally, he asked the question: "Would an ethically sound approach not be to emphasise an internal conviction and a sense of responsibility towards nature, rather than using scary tactics?",24

21 Madipoane Masenya (ngwa'na Mphahele) and Hulisani Ramantswana, “Anything New under the Sun of South African Old Testament Scholarship? African Qoheleth's Review of OTE 1994-2010," OTE 25/3 (2012): 599; Le Roux, A Story of Two Ways.

22 Deist, "South African," 34-51; Masenya (ngwa'na Mphahele) and Ramantswana, "Anything New?," 634.

23 S. Willie van Heerden, "Taking Stock of Old Testament Scholarship on Environmental Issues in South Africa: The Main Contributions and Challenges," OTE 22/3 (2009): 714.

24 Peet J. van Dyk, "Eco-Theology and Losing the Sacred," OTE 23/3 (2010): 822833. 


\section{Interpreting from Feminist/Womanist Perspectives}

After ten years of democracy Madipoane Masenya (ngwa'na Mphahele) revisited her bosadi (womanhood) approach to develop "an African methodology for South African Biblical Studies." She was concerned that many in the OT guild in South Africa did not perceive them to be "an integral part of the African continent." 25 Masenya (ngwa'na Mphahele) describes her bosadi ("womanhood") in terms of three basic commitments:

- The commitment to the African continent - especially to the context of African women;

- The commitment to the context of the modern Bible reader;

- The recognition that the Christian Bible played an important role among the South African communities of faith.

After all is said and done, the major hermeneutical focus for Masenya (ngwa'na Mphahele)'s bosadi approach "is the unique experiences of an African-South African woman, with a view to her liberation.,"26

Twenty year after the first democratic election, Masenya (ngwa'na Mphahele) recently reflected quite poignantly about the "insider-outsider" dilemma of being an African voice within the South African gender-sensitive discourse. The desire to "fit in" within one's sphere of operation is inherently human and that also applies to the academic space that is occupied by feminist theologies in Africa in relation to the global academic community. In conclusion, Masenya (ngwa'na Mphahele) chooses "not to mimic mainstream gendersensitive frameworks but to develop own home-grown, home-friendly frameworks, ones which would first give priority to the needs of local women." Although this choice might come at the price of slow upward academic mobility, the gender-sensitive scholar as an activist has no other choice because "charity of necessity has to begin at home, particularly given the historical deprivation of such home fronts."27

Julie Claassens combines feminist hermeneutics and literary theory in a creative and challenging manner. In contrast to angry and violent images of God in the OT, Claassens focuses in her monograph on neglected metaphors in the Bible that depict God as a mourner, mother, and midwife. This emergence

25 Madipoane Masenya (ngwa'na Mphahele), “An African Methodology for South African Biblical Sciences: Revisting the Bosadi (Womanhood) Approach," OTE 18/3 (2005): 741-751.

26 Masenya (ngwa'na Mphahele), “African Methodology,” 749.

27 Madipoane Masenya (ngwa'na Mphahele), "For Ever Trapped? An African Voice on Insider/Outsider Dynamics within South African Old Testament Gender-Sensitive Frameworks," OTE 27/1 (2014): 189, 201. 
of female imagery is interpreted against the backdrop of the Babylonian exile and she demonstrates how the Bible can be utilised as a resource to assist people who experienced trauma and bereavement. ${ }^{28}$

\section{Interpreting from a Philosophy of Religion Perspective}

The creative and challenging research by Jaco Gericke on developing a Philosophy of Religion perspective on the study of the OT or HB is fast gaining wide international recognition. Gericke draws attention to the absence of a historical account "devoted to tracing the references to philosophy of religion" in OT scholarly writings - it should not be confused with the tracing of "influential philosophical trends of the day."29

His own interests

have changed from critical a-theology and the deconstruction of biblical truth-claims to a more historical and descriptive type of philosophy of religion more focused on a clarification of the folkphilosophical assumptions in the biblical texts themselves. ${ }^{30}$

When engaging with a Philosophy of Religion perspective one has to realise that there was a movement in the twentieth century biblical theology that rejected philosophical views on Yahwism which has recently changed to "a more fruitful if partly reluctant involvement of philosophy for the understand-

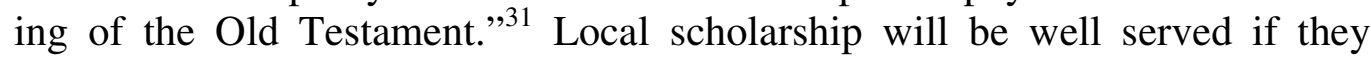
become more aware and appreciative of this emerging perspective on OT scholarship.

In a monograph, Gericke discusses the relationship between the $\mathrm{HB}$ and Philosophy of Religion in which he does not attempt "defending or criticizing Yahwistic religious beliefs to edify the ideological agenda of any religious or secular community of readers." He also does not have the desire to read (JudeoChristian) philosophy into the HB, nor any hope to construct a (Judeo-Christian) systematic philosophy of religion from its diverse contents. He is adamant that his sole academic agenda is "to pioneer a new approach within biblical studies aimed at a descriptive philosophical elucidation of the beliefs, concepts, and practices of ancient Israelite religion.",32

28 L. Juliana M. Claassens, Mourner, Mother, Midwife: Reimagining God's Delivering Presence on the Old Testament (Louisville: Westminster John Knox, 2012).

29 Jaco W. Gericke, "Old Testament Theology and Philosophy of Religion: A Brief History of Interdisciplinary Relations," OTE 23/3 (2010): 627.

30 Gericke, "Old Testament Theology," 627.

31 Gericke, "Old Testament Theology," 646.

32 Jaco W. Gericke, The Hebrew Bible and Philosophy of Religion (Atlanta: Society of Biblical Literature, 2012), 11. Local scholarship will be well served if they become more aware and appreciative of this emerging perspective on OT scholarship. 


\section{$7 \quad$ Interpreting from a Spirituality Perspective}

Christo Lombaard has done ground-breaking research in developing an interface between OT studies and Spirituality studies. He introduces "the academic discipline of Spirituality as a relatively new concretisation of what had long been happening within the university." Within "Spirituality as an academic discipline," there is "the on-going quest" for "(a) practical applicability" and "(b) philosophical depth" as well as searching for "more competing concrete theories for the discipline and its meta-theoretical grounding. ${ }^{, 33}$ It is important to note that in this approach to the Biblical text there is "the awareness" that in the reading of the text, the reader is himself or herself being read of interpreted.

In a collection of essays and papers, Lombaard describes the "the relationship between the Old Testament and Spirituality as an academic discipline" that does not primarily search for the relevance of the OT, but as an academic activity that presupposes that the Bible is a "book of faith" in which making sense of life and Christian practice play an important role. ${ }^{34}$ Recently, Lombaard has illustrated how historical critical exegesis can be combined with Spirituality studies in an article on Psalm 1. He points out that Biblical Spirituality must "not be confused with the pre-scientific, a- or anti-critical, and a- or anti-historical sentiments that are often assumed of the term "spirituality" because the dialectic between exegesis and spirituality makes exegesis to become "at once more historical and more spiritual..." He also identifies a few crucial methodological challenges that Biblical Spirituality must face up to: both "spiritual experience," as "the way in which faith impulses are internalised and given expression to" as well "mystic encounter," as the "peak experience of finding oneself in an unmediated (or less mediated) engagement with the Ultimate," will have to be subjected to rigorous scholarly scrutiny and debate. ${ }^{35}$

\section{A WAY FORWARD BY MEANS OF ANTONIO GRAMSCI AND PAULO FREIRE?}

Besides being "ants, spiders and bees," but preferably not "ticks," one must again ponder the question: Who are OT or HB scholars in South Africa? Does the Ben Sira description of the pursuit of wisdom by privileged intellectual élites with lots of leisure time ring true within our South African context?

The wisdom of the scribe depends on the opportunity of leisure; only the one who has little business can become wise.

33 Christo Lombaard, "The Mystifying Mosaic of Moses: On Pentateuch Theory and Biblical Spirituality," HTS 67/3 (2011), 1; Art. \#1121; DOI: doi.org/10.4102/hts .v67i3.1121.

34 Christo Lombaard, The Old Testament and Christian Spirituality (Atlanta, Ga.: Society of Biblical Literature, 2012), 18.

35 Christo Lombaard, "Mysticism and Understanding: Murmurs of Meaning (Fullness) - Unheard Silences of Psalm 1," OTE 27/2 (2014): 482, 483. 
How can one become wise who handles the plow, and who glorifies in the shaft of a goad,

who drives oxen and is occupied with their work, and whose talk is about bulls? (Sir 38:24-25).

Antonio Gramsci (1891-1937) was a well-known Marxist philosopher in Italy during Mussolini's Fascist regime and most of his thoughts can be found in the three volume Prison Notebooks. He argued that capitalism's grip on social control was not only established by violence and coercion, but also by ideology - in particular, middle class or bourgeoisie class values - and in this, cultural hegemony played an important role. Although all people are intellectuals, not all of them have the social function of intellectuals. Gramsci distinguished between "traditional intellectuals" who see themselves as a class apart from the society within which they exist; and "organic intellectuals" who do not simply describe social life and the surrounding reality in accordance to scientific theory. Instead, they articulate, through the language of the culture within which they are embedded, the feelings and experiences of the society ("the masses"!) which they cannot express for themselves (something amounting to an involved intellectual being a "participant articulator" of the needs and aspirations of the masses who goes beyond just being a "participant observer"). ${ }^{36}$ Therefore, Gramsci called for a system of education that developed "working-class intellectuals" whose task was to make the masses critical of the status quo.

But perhaps we need to add to Antonio Gramsci a little bit of Michel Foucault who believed that intellectuals should struggle against all forms of power within the domains of "knowledge," "truth," "consciousness" and "discourse." For Foucault, "grounded intellectuals" became and remained selfcritical of their roles as cogs in the machinery of power and knowledge within society. ${ }^{37}$ Accepting Gramsci without Foucault is to run the risk of allowing "underdogs or oppressed" to become "top dogs or oppressors" and repeating the wrongs of the past, against which they stood up whilst they were oppressed.

What is the future of intellectuals (OT theologians) in South Africa? How can we resolve the tension between the unflinching criticisms of power (state, market, organised religion, etc.) without becoming distanced intellectual élites? Can the essential commitment to the widows, the orphans, the poor and

36 Therefore, Gramsci called for a system of education that developed "workingclass intellectuals" whose task was to make the masses critical of the status quo. Antonio Gramsci, The Prison Notebooks (3 vols.; New York: Columbia Press, 1982).

37 Michel Foucault, The Archaeology of Knowledge (trans. A. M. Sheridan Smith; New York: Routledge, 1972). 
the stranger in our South African society escape from becoming an example of self-serving and smug egalitarianism? ${ }^{38}$

But this is not enough. We should also respond to the African proverb: "the children of snakes remain snakes." This must be translated within our South African position. Can intellectuals/ OT theologians transcend their class of origin (echoes of being a "tick")? Can fellow travellers and benefactors of Apartheid in the past be trusted and incorporated within the current and future reflection of making sense of the OT within the South African context?

Before drawing a few conclusions, I would like to pay attention to the work done by Paulo Freire (1921-1997), the Brazilian educator and philosopher, whose most influential work was Pedagogy of the Oppressed (1970), the foundational text for his concept of "critical pedagogy." He focused on the need to generate an education for indigenous populations that was new, modern and anti-colonial. Critical pedagogy must inculcate a sense of self-critical awareness amongst oppressors and oppressed that allows the oppressed to regain their sense of humanity (in a certain sense, this also applies to the oppressors who damaged their own humanity while oppressing others). For Freire, education was a political act that could not be divorced from pedagogy. The way students are taught and what they are taught inevitably serves a political agenda." One may well ask: "Do Old Testament lecturers realise this responsibility?"

A last word on a neglected aspect of Freire's educational philosophy is the role of laughter! "It's necessary to laugh with the people because if we don't do that we cannot learn from the people, and in not learning from the people we cannot teach them." 40

\section{E CONCLUSION}

More than three millennia ago, an Egyptian wisdom text reflected on the legacy of a scribe thus:

38 Charles Kurzman and Lynn Owens, "The Sociology of Intellectuals," ARSOc 28 (2002): 81.

39 Paulo Freire, Pedagogy of the Oppressed (New York: Continuum, 1993 [1970]).

40 Myles Horton and Paulo Freire, "Reflections," in We Make the Road by Walking: Conversations on Education and Social Change (ed. Brenda Bell, John Gaventa and John Peters; Philadelphia, Pa.: Temple University Press, 1990), 247. Take note of the comedians who perform as news anchors such as Jon Stewart, Stephen Colbert and recently Trevor Noah and who incite laughter that is critical of contemporary politics. Mention must also be made of two fine commentaries recently written by South African OT scholars namely Louis Jonker on 1 and 2 Chronicles, and Fanie Snyman on Malachi. See Louis C. Jonker, 1 and 2 Chronicles (UBCS; Grand Rapids: Baker Academic, 2013); S. D. (Fanie) Snyman, Malachi (HCOT; Leuven: Peeters, 2014). 
Their tombstones are covered with dirt; and their graves are forgotten.

But their names are still pronounced because of the books they made,

since they were good and the memory of him who made them lasts for eternity. ${ }^{41}$

In the same way, current OT scholars should reflect on the impact and legacy their research will have in the future. Again, I suggest that one's conclusions about OT scholarship in South Africa must be related to its academic counterparts on the African continent and be embedded in the cultures within which these critical dialogues take place. ${ }^{42}$ Africa is a continent with a bewildering diversity of languages and cultures. Amidst certain commonalities, its enriching and challenging diversity must not be lost in translating it into "Africa." Ironically, Africa's "other," the "West," must also be deconstructed. This "West" had a past permeated with a Greco-Roman culture, by definition, a

41 In Joseph Blenkinsopp, Wisdom and Law in the Old Testament: The Ordering of Life in Israel and Early Judaism (OxBS; Oxford: Oxford University Press, 1983), 8.

42 When reflecting on the prospects of biblical interpretation in Africa, I recently came to the following conclusions:

"The interface between academic and popular interpretations of the Old Testament will remain an important concern for most African members of the guild of Biblical scholarship. This inevitable emphasis on reception, however valid, cannot afford any blanket disdain for matters related to the critical investigation of the text as a literary and as a historical phenomenon [this not only applies to bees, but also to ants and spiders!]

There is much room for the critical engagement by biblical scholars who want to explore the contested spaces created by diverging modes of scholarship. Old Testament scholarship in Africa should not aspire to establish one common method in biblical interpretation but rather to develop models of interpretation that reflect cultural and religious diversity and make sense to local interpretive communities.

Political correctness should not lull African biblical scholarship into a complacent rejection of any dissenting voices. Many a disastrous socio-economic and political experiment was allowed to come into fruition in Africa with little significant challenges forthcoming from critically engaged biblical scholarship responsibility Truth to power remains an on-going responsibility, also when underdogs become top dogs!

In various academic disciplines writing about Africa has been burdened with pessimistic and formulaic representations about a continent bogged down in a supposed quagmire of disease, poverty, superstition and an endemic lack of academic infrastructure and endeavour. Africa, however, is the continent where Christianity grows the fastest and where the Bible still has a special place in worship. Time will tell whether interpretive communities in Africa will succeed to create interpretations of Scripture that address the wholeness of life from the perspective of a wholeness of being - an ability that has been lost in many other parts of the globe where academic specialization and a fragmentation of being have taken its toll." Bosman, "Hebrew Bible/Old Testament," 267-268. 
Mediterranean culture that was influenced over millennia by the Near East and Northern Africa. The "West" is much more than its colonial face that created havoc on different continents including Africa.

One dangerous form of political correctness in the interpretation of the OT is "Afrocentric exaggeration" that claims that African Theology "became normative for all aspects of ancient ecumenical Christianity" without engaging with these sources in a critical and constructive manner. ${ }^{43}$

Amidst a diversity of societies in Africa, patriarchy in different shapes and sizes has disallowed a strong female voice in African OT scholarship. This under-representation of women as students and scholars is in stark contrast to the overwhelming majority of women sitting in the pews of churches across the African continent. ${ }^{44}$

May this article be a small contribution that would stimulate reflection on how to cross the divide between the "now" of the current biblical readers in different parts of Africa and the "then" of the production of the biblical text... some 2500 and more years ago. But while doing this we will have to translate Lessing's notorious "garstige breite Grabe" between "the now of biblical reception" and "the then of biblical text production," not by its English translation "ugly" or "nasty ditch" but by a word commonly used in Southern Africa which is of Nguni origin, the word "udonga" (meaning, wall or fence). ${ }^{45}$ Close cooperation between ants, spiders and bees will be required to get OT scholarship across this "nasty donga"!

The very important debate about how to interpret the Bible from different African perspectives in conjunction with the existing new developments within our OT guild that is manifested in the interpretations from eco-theological, feminist/womanist, philosophy of religion and spirituality perspectives are indications that several busy bees are at work in our midst. This trend augurs

43 Thomas C. Oden, How Africa Shaped the Christian Mind: Rediscovering the African Seedbed of Western Christianity (Downers Grove: IVP Books, 2007), 76-77.

Yamauchi rejects any Eurocentric approach that disallows an African presence in the Bible as well as certain Afrocentric biblical interpretations that assume that all Africans were black and that everything of value originated in Africa. Edwin M. Yamauchi, Africa and the Bible (Grand Rapids: Baker Academic, 2004).

44 H. Jurgens Hendriks et al., eds., Men in the Pulpit, Women in the Pew: Addressing Gender Inequality in Africa (Stellenbosch: African Sun, 2012).

45 Gotthold E. Lessing, "Über den Beweis des Geistes und der Kraft," in Die Erziehung des Menschengeschlechts und andere Schriften (ed. Gotthold E. Lessing; Stuttgart: Reclam, 1956 [1777]). He says: "Das, das der garstige breite Grabe, über den ich nicht kommen kann, sooft und ernstlich ich auch den Spruch versucht habe. Kann mir jemand hinüberhelfen..." 
well for the future of OT studies in South Africa (despite the nagging suspicion about the ongoing presence of "ticks" amongst us!) $)^{46}$

In August and September you can hear the black cuckoo (cuculus clamosus) calling in the veld, indicating that spring is on its way. May the global scholarly community soon (hopefully not later than the next generation?) take note of a spring taking place in South Africa and across the continent of Africa where the OT is read and interpreted in such a manner that it enables a meaningful life for all - old and young, poor and rich, female and male!

This reading and interpretation of the OT will have to be informed by a historical consciousness related to the production and the reception of the biblical text as well as an ethics of reading the Bible permeated by vulnerability in the fragile (but hopefully resilient) dialogue with those who differ from us - the "other" without whom no critical self-understanding is possible. To maintain this vulnerable but resilient dialogue, OT scholars need not only "a leap of faith" but even more acutely a "leap of trust," undergirded by rigorous criticism performed in humble acknowledgment of our interconnectedness.

How can "organic intellectuals" maintain a self-critical awareness of the inevitable and pervasive influence of power, and be able to produce "theological honey" that can challenge and nurture a society in need of making sense of its precarious existence? OT scholars in South Africa must face up to the challenge and the responsibility of producing "theological honey" - time will tell whether we were able to do so.

\section{BIBLIOGRAPHY}

Bacon, Francis. Novum Organum. Translated and edited by Peter Urbach and John Gibson. Chicago: Open Court, 1994 [1620].

Blenkinsopp, Joseph. Wisdom and Law in the Old Testament: The Ordering of Life in Israel and Early Judaism. Oxford Bible Series. Oxford: Oxford University Press, 1983.

Bosman, Hendrik L. "The Hebrew Bible/Old Testament Studies in Africa." Pages 253-268 in From Modernism to Post-Modernism (The Nineteenth and Twentieth Century). Volume 3 of The Hebrew Bible/Old Testament: The History of Its

\footnotetext{
46 White OT scholars in South Africa in general had a privileged education and often presumed that they had a type of "noblesse oblige" to produce scholarship on behalf of the poor and disadvantaged in the South African society. To steer clear of an arrogant and exploitative hermeneutics that disregards the "other" in need is an ongoing responsibility within white South African scholarship. There is a need to strive towards becoming "bees" (organic intellectuals engaged with the trials and tribulations of the society as a whole), and shy away from becoming parasitic "ticks" who are primarily more interested in furthering their own careers than in engaging with societal problems.
} 
Interpretation. Edited by Magne Saebo. Göttingen: Vandenhoeck \& Ruprecht, 2015.

Claassens, L. Juliana M. Mourner, Mother, Midwife: Reimagining God's Delivering Presence on the Old Testament. Louisville: Westminster John Knox, 2012.

Deist, Ferdinand E. "South African Old Testament Studies and the Future." Old Testament Essays 7/4 (1994): 34-51.

Foucault, Michel. The Archaeology of Knowledge. Translated by A. M. Sheridan Smith. NewYork: Routledge, 2002 [1972].

Freire, Paulo. Pedagogy of the Oppressed. New York: Continuum, 1993 [1970].

Gericke, Jaco W. "Old Testament Theology and Philosophy of Religion: A Brief History of Interdisciplinary Relations.” Old Testament Essays 23/3 (2010): 627651.

. The Hebrew Bible and Philosophy of Religion. Atlanta: Society of Biblical Literature, 2012.

Giere, Samuel D. "“As a Bee Gathers Honey': The Rule of Faith in Luther's Interpretation of the Old Testament." Currents in Theology and Mission 41 (2014): 39-44.

Gramsci, Antonio. The Prison Notebooks. 3 vols. New York: Columbia Press, 1982.

Hendriks, H. Jurgens, Elna Mouton, L. D. Hansen and Elisabet le Roux, eds. Men in the Pulpit, Women in the Pew: Addressing Gender Inequality in Africa. Stellenbosch: African Sun, 2012.

Horton, Myles and Paolo Freire. "Reflections." Pages 227-249 in We Make the Road by Walking: Conversations on Education and Social Change. Edited by Brenda Bell, John Gaventa and John Peters. Philadelphia, Pa.: Temple University Press, 1990.

Jonker, Louis C. 1 and 2 Chronicles. Understanding the Bible Commentary Series. Grand Rapids: Baker Academic, 2013.

Kurzman, Charles and Lynn Owens. "The Sociology of Intellectuals." Annual Review of Sociology 28 (2002): 63-90.

Le Roux, Jurie H. A Story of Two Ways: Thirty Years of Old Testament Scholarship in South Africa. Pretoria: Verba Vitae, 1993.

Lessing, Gotthold E. "Über den Beweis des Geistes und der Kraft.” Pages 196-197 in Die Erziehung des Menschengeschlechts und andere Schriften. Edited by Gotthold E. Lessing. Stuttgart: Reclam, 1956 [1777].

Lombaard, Christo. "The Mystifying Mosaic of Moses: On Pentateuch Theory and Biblical Spirituality." HTS Teologiese Studies / Theological Studies 67/3 (2011). Art. \#1121. 5 pages. DOI: doi.org/10.4102/hts .v67i3.1121.

. The Old Testament and Christian Spirituality. Atlanta, Ga.: Society of Biblical Literature, 2012.

. "Mysticism and Understanding: Murmurs of Meaning (Fullness) - Unheard Silences of Psalm 1." Old Testament Essays 27/2 (2014), 472-488.

Maluleke, Tinyiko S. and Sarojini Nadar. "Alien Fraudsters in the White Academy: Agency in Gendered Colour." Journal of Theology for Southern Africa 120 (2004): 5-17.

Masenya (ngwa'na Mphahele), Madipoane. "An African Methodology for South African Biblical Sciences: Revisiting the Bosadi (Womanhood) Approach." Old Testament Essays 18/3 (2005): 741-751. 
. "For Ever Trapped? An African Voice on Insider/Outsider Dynamics within South African Old Testament Gender-Sensitive Frameworks." Old Testament Essays 27/1 (2014): 189-204.

Masenya (ngwa'na Mphahele), Madipoane and Hulisani Ramantswana. "Anything New under the Sun of South African Old Testament Scholarship? African Qoheleth's Review of OTE 1994-2010." Old Testament Essays 25/3 (2012): 598-637.

Mbiti, John S. Bible and Theology in African Christianity. Nairobi: Oxford University Press, 1986.

Mosala, Itumeleng J. Biblical Hermeneutics and Black Theology in South Africa. Grand Rapids: Eerdmans, 1989.

Mtshiselwa, Ndikho. "Towards an Indigenous (Xhosa) South African Biblical Scholarship." Old Testament Essays 24/3 (2011): 668-689.

Muntersbjorn, Madeline M. "Francis Bacon's Philosophy of Science: Machina Intellectus and Forma Indita." Philosophy of Science 70 (2003): 1137-1148.

Oden, Thomas C. How Africa Shaped the Christian Mind. Rediscovering the African Seedbed of Western Christianity. Downers Grove: IVP Books, 2007.

Segovia, Fernando F. "Biblical Criticism and Postcolonial Studies: Toward a Postcolonial Optic." Pages 49-51 in The Bible and Postcolonialism. Edited by Rasiah S. Sugirtharajah. Sheffield: Academic Press, 1998.

Snyman, Gerrie F. "'Looking into Black Eyes and Feel the Embarrassment': A Selected and Selective Reading of the Africana Bible." Old Testament Essays 24/2 (2011): 464-491. 10. . "Editorial: Epistemic Vulnerability." Old Testament Essays 28/1 (2015): 9-

Snyman, S. D. (Fanie). Malachi. Historical Commentary on the Old Testament. Leuven: Peeters, 2014.

Van Dyk, Peet. "Eco-theology and Losing the Sacred." Old Testament Essays 23/3 (2010): 822-833.

Van Heerden, S. Willie. "Taking Stock of Old Testament Scholarship on Environmental Issues in South Africa: The Main Contributions and Challenges." Old Testament Essays 22/3 (2009): 695-718.

West, Gerald O. Biblical Hermeneutics of Liberation: Modes of Reading the Bible in the South African Context. Pietermaritzburg: Cluster Publications, 1991.

. "The Vocation of a Biblical Scholar on the Margins of Biblical Scholarship." Pages 142-171 in Voyages in Unchartered Waters: Essays on the Theory and Practice of Biblical Interpretation in Honour of David Jobling. Edited by Wesley J. Bergen and Armin Siedlecki. Sheffield: Sheffield Phoenix Press, 2006.

. 'Locating 'Contextual Bible Study' within Liberation Hermeneutics and Intercultural Biblical Hermeneutics.” HTS Teologiese Studies / Theological Studies 70/1 (2014), 10 pages. Art. \#2641. DOI: org/10.4102/hts.v70i1.2641. Yamauchi, Edwin M. Africa and the Bible. Grand Rapids: Baker Academic, 2004.

Prof. Hendrik Bosman, Department of Old and New Testament, University of Stellenbosch. Email: hlb1@sun.ac.za. 